\title{
E-DATA: A Comprehensive Field Campaign to Investigate Evaporation Enhanced by Advection in the Hyper-Arid Altiplano
}

\author{
Francisco Suárez ${ }^{1,2,3, *(\mathbb{D})}$, Felipe Lobos ${ }^{1,4}$, Alberto de la Fuente ${ }^{5}$ (D), \\ Jordi Vilà-Guerau de Arellano ${ }^{4}\left(\mathbb{D}\right.$, Ana Prieto ${ }^{5}$, Carolina Meruane ${ }^{5,6}$ and Oscar Hartogensis 4 \\ 1 Departamento de Ingeniería Hidráulica y Ambiental, Pontificia Universidad Católica de Chile, \\ Santiago 7820436, Chile; felipe.lobosroco@wur.nl \\ 2 Centro de Desarrollo Urbano Sustentable (CEDEUS), Santiago 7820436, Chile \\ 3 Centro de Excelencia en Geotermia de los Andes (CEGA), Santiago 7820436, Chile \\ 4 Meteorology and Air Quality Section, Wageningen University and Research, 6700 AA Wageningen, \\ The Netherlands; jordi.vila@wur.nl (J.V.-G.d.A.); oscar.hartogensis@wur.nl (O.H.) \\ 5 Departamento de Ingeniería Civil, Universidad de Chile, Santiago 8370448, Chile; \\ aldelafu@ing.uchile.cl (A.d.l.F.); ana.prieto@uchile.cl (A.P.); cmeruane@modelacion.cl (C.M.) \\ 6 Modelación Ambiental SpA, Santiago 7500015, Chile \\ * Correspondence: fsuarez@ing.puc.cl
}

Received: 29 January 2020; Accepted: 5 March 2020; Published: 8 March 2020

\begin{abstract}
In the endorheic basins of the Altiplano, water is crucial for sustaining unique ecological habitats. Here, the wetlands act as highly localized evaporative environments, and little is known about the processes that control evaporation. Understanding evaporation in the Altiplano is challenging because these environments are immersed in a complex topography surrounded by desert and are affected by atmospheric circulations at various spatial scales. Also, these environments may be subject to evaporation enhancement events as the result of dry air advection. To better characterize evaporation processes in the Altiplano, the novel Evaporation caused by Dry Air Transport over the Atacama Desert (E-DATA) field campaign was designed and tested at the Salar del Huasco, Chile. The E-DATA combines surface and airborne measurements to understand the evaporation dynamics over heterogeneous surfaces, with the main emphasis on the open water evaporation. The weather and research forecasting model was used for planning the instruments installation strategy to understand how large-scale air flow affects evaporation. Instrumentation deployed included: meteorological stations, eddy covariance systems, scintillometers, radiosondes and an unmanned aerial vehicle, and fiber-optic distributed temperature sensing. Additional water quality and $\mathrm{CO}_{2}$ fluxes measurements were carried out to identify the link between meteorological conditions and the biochemical dynamics of Salar del Huasco. Our first results show that, in the study site, evaporation is driven by processes occurring at multiple spatial and temporal scales and that, even in the case of available water and energy, evaporation is triggered by mechanical turbulence induced by wind.
\end{abstract}

Keywords: Salar del Huasco; surface energy balance; evaporation; advection; multiscale processes; eddy covariance; scintillometers; radiosounding; distributed temperature sensing

\section{Introduction}

The hydrological functioning of the high Andean basins in the Altiplano region is characterized by semi-arid to hyper-arid climate and endorheic conditions [1]. In this area, water is crucial for natural habitats, industry, and agriculture. The area is rain-fed by occasional convective showers that are 
spatially very localized and temporally rapidly changing in intensity $(<1 \mathrm{~h})$. These rainstorms are the source of aquifer recharge and thus they sustain wetlands that are formed in the basins due to surface discharge and groundwater upwelling. The high Andean wetlands sustain unique ecological habitats, being home to the most threatened bird species [2-4]. The wetlands act as highly evaporative environments and thus, it is where nearly all the water of the basin is lost to the atmosphere [4]. In this region, a reliable understanding of the evaporation processes is extremely essential for several reasons. First, the correct quantification of water fluxes enhances the performance of water balance models, e.g., by assimilating the evaporation data or improving the fluxes parametrizations. As a result, the estimation of the basin's water recharge can be improved $[4,5]$. Second, water availability is fundamental for terrestrial and aquatic ecosystems that sustain the native flora and fauna $[3,4,6,7]$. Lastly, for sustainable water use with minimum impact into the environment $[8,9]$.

The climatic conditions of the Altiplano region, on the other hand, are closely related to the zonal winds, in which easterly zonal flows favor wet conditions in summer (mid-December to mid-March) because of the entry of humid air from the Amazon region, and westerly zonal flows have associated drier conditions mainly during winter and spring [10]. In this way, the combination of synoptic and mesoscale phenomena has an important role in the evaporation rates of this region. In fact, in a long-term perspective, de la Fuente and Meruane [11] have shown that because of a reduction in the magnitude of the zonal wind, potential evaporation has decreased in Salar del Huasco by $10 \%$ to $20 \%$ with respect to the second half of the twentieth century. Furthermore, these environments may also be subject to evaporation enhancement episodes as the result of dry air advection, changes in wind speed, and air and soil temperature, which complicate even more the determination of the evaporation fluxes [12-17]. These episodes occur at sub-hourly temporal scales. The relevant spatial scales for studying evaporation in these environments are typically in between the scales that can be resolved using traditional evaporation methods [18]: much larger than those of traditional in-situ methods (e.g., evaporation pans, lysimeters), but typically smaller than those based on remote sensing through satellites. Similarly, the heterogeneity of the surface conditions, i.e., water, wet salt, and desert, is characterized by $100-\mathrm{m}$ scales, which requires parameterizations in weather forecast and climate models, as well as hydrological models, i.e., sub-grid scale phenomena.

Evaporation is strongly influenced by the connection between the land surface and the atmosphere [19], but there is few of this information in the Altiplano region [2]. In the open waters of the high Andean wetlands, de la Fuente and Niño [3] used a thermodynamic model to estimate mean daily evaporation rates of $\sim 8 \mathrm{~mm} \mathrm{day}^{-1}$, with peaks reaching values of $\sim 40 \mathrm{~mm}$ day $^{-1}$. Also, mean daily pan evaporation rates as large as $\sim 11 \mathrm{~mm}^{\text {day }}{ }^{-1}$ have also been reported [20]. The evaporation rates measured in these lagoons and their wetlands exceeded the evaporation values that can be expected from net-radiation estimates, but the processes associated to these large fluxes have not been studied. Consequently, our working hypothesis is that advection of dry air combined with high wind enhancing mechanical turbulence coming from the surroundings of shallow lagoons in endorheic basins of the Altiplano region is the responsible for large actual evaporation rates. To truly understand the contribution of advection to evaporation in these environments, the transport processes that occur in the atmospheric boundary layer (ABL) must be explored. The ABL is a variable-thickness layer that connects the land surface with the free troposphere, and where transport of momentum, thermal energy, and specific humidity occurs [21,22].

The coupling between the evaporation that occurs in the highly evaporative environments of the Altiplano and the ABL processes has not been fully explored yet. To improve the understanding of the relevant processes that drive evaporation in these environments, we designed and carried out an extensive field experiment called Evaporation caused by Dry Air Transport over the Atacama Desert (E-DATA), with a focus on the effect that advection has on evaporation rates, and to obtain diurnal budgets of heat and water under the most characteristic surfaces in these Altiplano environments. This article presents the methods used for the experimental design and the implementation of the E-DATA field experiment, and discusses the implications of this field experiment for further investigation by 
presenting and analyzing our first results. The 10-day field campaign was designed to understand the evaporation dynamics over heterogeneous surfaces with emphasis on open water evaporation at different spatial scales, and under the extreme conditions in Salar del Huasco, Chile (high radiation levels, large daily thermal oscillation and strong winds during the afternoon). The novelty of this field experiment is that it combines surface and airborne measurements to quantify the moisture and heat transport, accounting for the interaction between the ABL and the regional circulation. In addition, the collected data can be combined with numerical simulations using the conceptual chemistry land-surface atmosphere soil slab (CLASS) model [22] and more sophisticated simulations of the weather and research forecasting (WRF) model [23] to understand the main processes that control evaporation in these environments. Therefore, this work provides a rich methodology that will be used later in more in-depth studies.

\section{Study Site}

The Salar del Huasco basin is located between $19^{\circ} 54^{\prime}$ and $20^{\circ} 27^{\prime} \mathrm{S}$ and between $68^{\circ} 40^{\prime}$ and $69^{\circ} 00^{\prime} \mathrm{W}$ in the Atacama Desert (Figure 1) and sits on the so-called Depresión de los Salares (salt flats depression), surrounded by high peaks ranging between 4000 and $5200 \mathrm{~m}$ a.s.1. [24]. This closed basin has high environmental relevance as it hosts a variety of camelids and birds in high-altitude wetlands. In the particular case of Salar del Huasco, it is located at an altitude of $\sim 3800 \mathrm{~m}$ a.s.l. and is home to protected bird species such as flamingos [25]. Because of that, Salar del Huasco is protected under the international Ramsar convention, which recognizes the ecological, economic, cultural, and scientific value of different wetlands around the world [26].
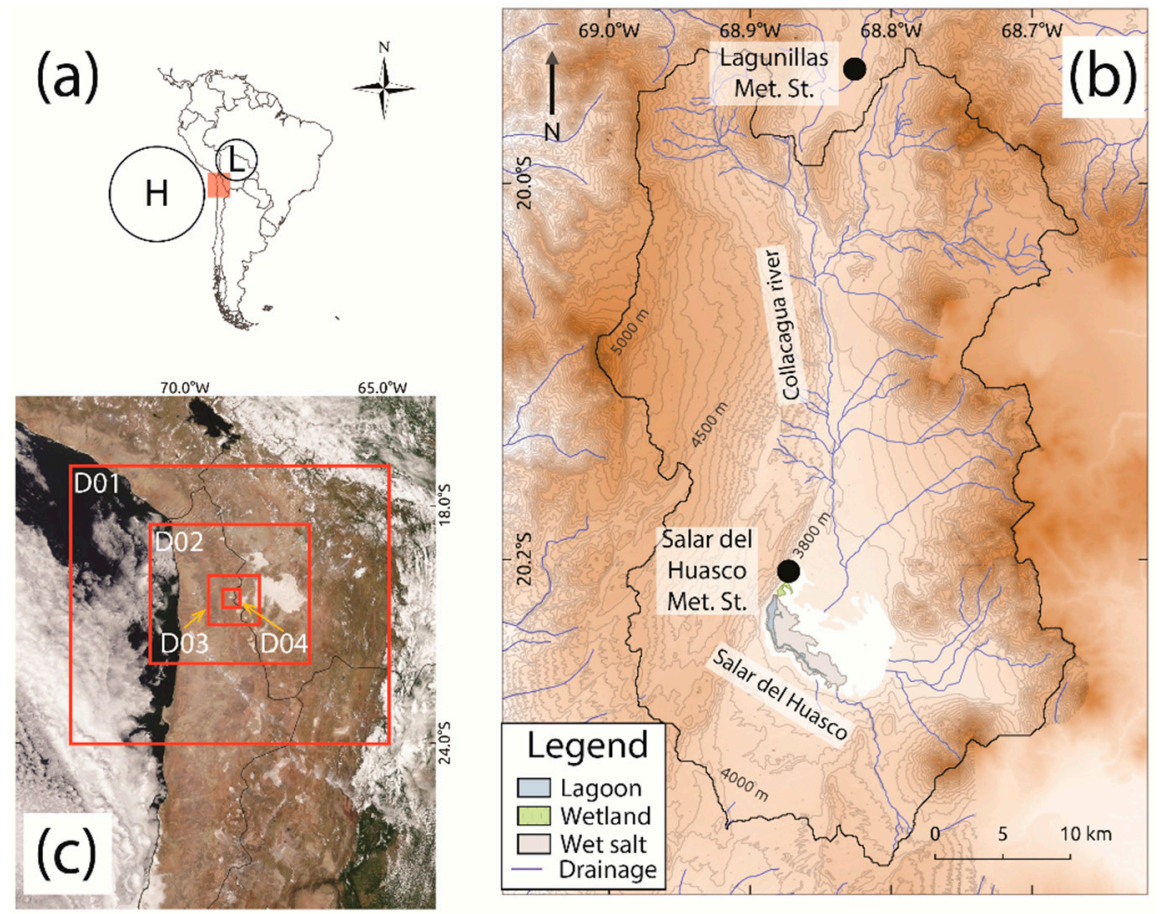

Figure 1. (a) General location of the study site. H and L depicts high- and low-pressure systems, respectively, which controls the meteorological behavior in the basin. (b) Salar del Huasco basin and meteorological stations used in the climatological analysis. (c) Domains (D01, D02, D03 and D04) used in the Weather and Forecasting (WRF) model simulations for the design of the field experiment.

Rainfall in the basin and across the Altiplano region is convective with more than $80 \%$ occurring between December and March [24,27]. The annual mean precipitation in the basin is $135 \mathrm{~mm}$ for the 1962-2014 time period. Interannual precipitation variability is high, partially due to the El Niño 
southern oscillation phenomenon (ENSO), but mostly due to the wind patterns in the area [28]. Mean annual potential evaporation is approximately $1200 \mathrm{~mm}$ and it has been relatively stable between 1950 to present with variations of up to $20 \%$ in the last two decades [11]. Rainfall and evaporation from the wetlands seem to be the only water inputs and outputs in the basin [24].

The Salar del Huasco was selected as the study site because it is one of the few places in the Altiplano region in which evaporation data have been previously collected and thus there is evidence that dry air advection may be occurring $[4,11,25]$. In this closed basin, local atmospheric circulation may be relevant for the surface energy balance [29].

\section{Design and Implementation of the E-DATA Field Experiment}

\subsection{Design of the Study}

To improve the understanding of the relevant processes that drive evaporation it is important to couple the land-surface processes to those occurring in the ABL. For this reason, the first stage of the study was to define the month in which the field campaign was going to take place. Then, a thorough analysis of the wind patterns at both the local and regional scales was performed, with a focus on the open waters of the Salar del Huasco basin. This analysis was used to define the location of the different instruments in the field experiment.

A climatological analysis was carried out using historical meteorological information obtained from the Lagunillas and Salar del Huasco meteorological stations (Figure 1). Using these data, we analyzed the wet and dry seasons. On the one hand, the wet season, which occurs between mid-December and mid-March, is characterized by small daily thermal oscillations, high specific humidity $\left(>5.0 \mathrm{~g} \mathrm{~kg}^{-1}\right)$ and precipitation that is spatially very localized and rapidly changing in time. On the other hand, the dry season that occurs between mid-March and mid-December, is characterized by large daily thermal oscillations, low specific humidity $\left(<2.5 \mathrm{~g} \mathrm{~kg}^{-1}\right)$ and no precipitation. Hence, we selected November as the best month in the dry season to test our working hypothesis, because of the temperature contrast between ambient and water temperature, large availability of solar radiation, and absence of precipitation, which are the more optimal conditions to study dry advection episodes.

The spatial configuration of the different instruments used in the E-DATA field campaign was designed by analyzing the wind patterns for the months of November 2015-2017. This analysis was carried out using in-situ surface observations from the Salar del Huasco meteorological station and simulation results of a WRF (version 3) model [23] in the study site. The domains used in the WRF simulations are presented in Figure 1c. The domains have a spatial resolution of $27 \mathrm{~km}$ (D01), $9 \mathrm{~km}$ (D02), $3 \mathrm{~km}$ (D03), and $1 \mathrm{~km}$ (D04). Thirty levels were defined in the vertical direction, from which 20 are in the first $2000 \mathrm{~m}$ above ground level. This relatively high spatial resolution and the large nested domains enable to model all the relevant atmospheric phenomena acting at different scales, and include the differences in topography and surface conditions. The main WRF parametrizations were: the CAM5 scheme for boundary layer physics [30], the RRTMG model for radiation physics [31], and the unified Noah land-surface model for land surface physics [32]. The parametrization schemes are based on a standard WRF model run that yields representative results in the Atacama Desert [33]. We followed the method proposed by Jiménez et al. [34] to perform the WRF simulations: consecutive two-days WRF model runs initiated at 0 UTC were executed. The first day of simulation corresponded to the spin-up of the physical parametrization and the second day was used to represent the weather conditions of the study site. The initial and boundary conditions are taken from the ECMWF ERA-interim reanalysis data for $20^{\circ} \mathrm{S}-68^{\circ} \mathrm{W}$ with spatial and temporal resolutions of $79 \mathrm{~km}$ and six hours, respectively [35]. We applied this initialization method to ensure that the WRF simulations remain close to the ERA-Interim synoptic conditions. The temporal resolution of the output data was one hour. The results of the WRF simulations, in the D04 domain, were validated against in-situ data collected at the Salar del Huasco meteorological station, obtaining determination coefficients $\left(\mathrm{r}^{2}\right)$ of $0.98,0.77$, and 0.92 for air temperature, specific humidity, and wind speed, respectively $(p>0.005)$. 
The criteria to select the locations of the instruments was to deploy them in different surfaces and align them in the principal wind directions. On the one hand, the in-situ data showed a predominant wind direction coming from the southwest and provided a point-in-space temporal overview of the wind behavior. On the other hand, the WRF simulations, which gave a perspective of the spatiotemporal patterns of the atmospheric circulation in the study area, showed that the main wind directions are southwest and west, where topographic effects result in air being channeled from the southwest direction at the location of the Salar del Huasco meteorological station. Figure 2 shows the location of each instrument used during the E-DATA field experiment. The instrumentation, which is described in more detail in the next subsection, was deployed to monitor evaporation and other relevant meteorological variables that help to understand the ABL processes, as well as to investigate biogeochemical processes in open waters and their surroundings that could also be driven by evaporation.

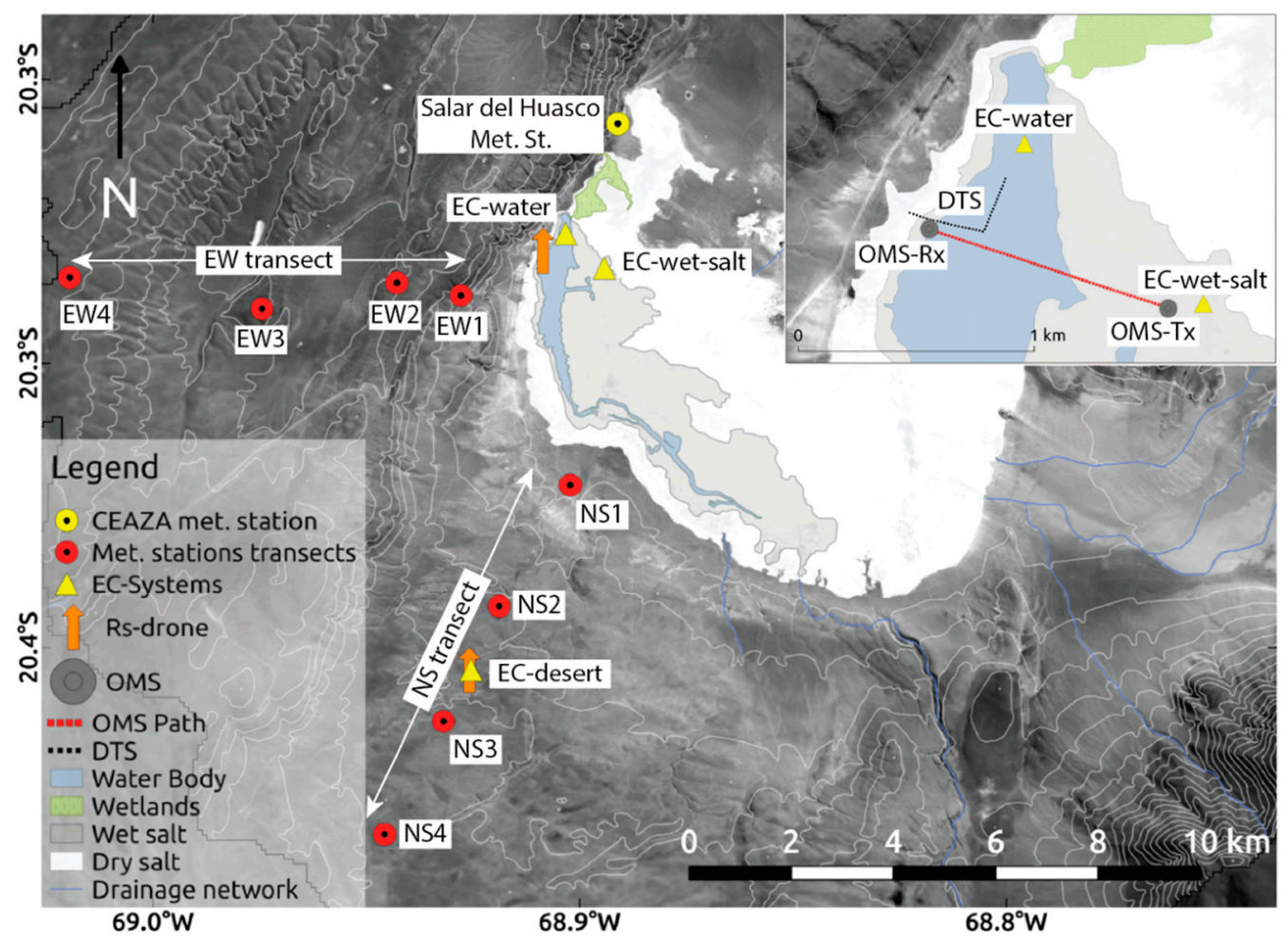

Figure 2. Location of the instruments in the E-DATA field campaign.

\subsection{Implementation of the E-DATA Field Experiment}

The E-DATA field experiment was carried out between 12 and 26 November 2018, and data were collected for 10 days, making it the longest field experiment that has been performed in the Altiplano region with the aim of studying evaporation. Instrumentation deployed included: eight meteorological stations, three eddy covariance (EC) systems, one optical-microwave scintillometer (OMS), 16 radiosondes and an unmanned aerial vehicle (UAV), and fiber-optic distributed temperature sensing (DTS) measurements along a 620-m path. The link between meteorological conditions and the biochemical dynamics of open waters in the saline lake was also investigated, and the following biogeochemical parameters were measured: $\mathrm{CO}_{2}$ fluxes, water temperature, turbidity and dissolved oxygen (DO), and several water quality parameters. Table 1 presents the sensor types and manufacturer information of each measuring system. Figure 3 presents photographs of the saline lake and of the different instruments used in the field campaign. These instruments were used to monitor evaporation and other relevant variables in the ABL. In the next subsections, each instrumentation group is described. 
Table 1. Description of the instrumentation used in the E-DATA field experiment. Numbers refer to the footnotes of the Table, where sensor type and manufacturer information is provided.

\begin{tabular}{cccccccc}
\hline Variable & $\begin{array}{c}\text { EC- } \\
\text { Water }\end{array}$ & $\begin{array}{c}\text { EC- } \\
\text { Desert }\end{array}$ & $\begin{array}{c}\text { EC- } \\
\text { Wet-Salt }\end{array}$ & OMS & DTS & $\begin{array}{c}\text { Met. St. } \\
\mathbf{1 - 8}\end{array}$ & $\begin{array}{c}\text { Salar del } \\
\text { Huasco Met. St. }\end{array}$ \\
\hline Incoming shortwave rad. & 1 & - & - & - & - & - & 22 \\
Incoming longwave rad. & 1 & - & - & - & - & - & - \\
Outgoing shortwave rad. & 1 & - & - & - & - & - & - \\
Outgoing longwave rad. & 1 & - & - & - & - & - & - \\
Net shortwave radiation & 1 & 8 & - & - & - & - & - \\
Net longwave radiation & 1 & 8 & - & - & - & - & - \\
Total net radiation & 1 & 8 & 12 & - & - & - & - \\
Photosynthetic active rad. & - & - & 13 & & & & - \\
Latent heat flux & 2 & 2 & 2 & 14,15 & - & - & - \\
Sensible heat flux & 2 & 2 & 2 & 14,15 & - & - & - \\
Soil heat flux & 3 & 9,10 & 9,10 & & - & - & - \\
Soil temperature & - & 4,11 & 4,10 & & - & - & - \\
Water temperature & 4 & - & - & - & 17 & - & 5 \\
Wind speed & 2,5 & 2 & 2 & 16 & - & 18,19 & 23 \\
Air temperature & 2,6 & 2,4 & 2 & 16 & 17 & 20,21 & 7 \\
Relative humidity & 2,6 & 2 & 2 & 16 & - & 20,21 & 21 \\
Atmospheric pressure & 2,7 & 2,7 & 2 & 16 & - & - & 24 \\
Precipitation & - & - & - & 16 & - & - & - \\
\hline
\end{tabular}

${ }^{1}$ CNR4 Net radiometer, Kipp \& Zonen, Delft, The Netherlands; ${ }^{2}$ IRGASON, Campbell Sci., Logan, UT, USA; ${ }^{3}$ 31/32 Heat flux meter, TNO Institute of Applied Physics, The Netherlands; ${ }^{4} 107$ Temperature probe, Campbell Sci., Logan, UT, USA; ${ }^{5}$ 05108-45-L Wind Monitor-HD, R. M. Young Company, Traverse City, Michigan, US; ${ }^{6}$ HPM155 Humidity and temperature probe, Vaisala, Helsinki, Finland; ${ }^{7}$ PTB110 Barometer, Vaisala, Helsinki, Finland; ${ }^{8}$ CNR2 Net radiometer, Kipp \& Zonen, Delft, The Netherlands; ${ }^{9}$ HFP01SC Self-calibrating heat flux sensor, Hukseflux, Delft, The Netherlands; ${ }^{10}$ HFP01 Heat flux sensor, Hukseflux, Delft, The Netherlands; ${ }^{11}$ TCAV-L Averaging soil thermocouple probe, Campbell Sci., Logan, UT, USA; ${ }^{2}$ NR2 Lite, Kipp \& Zonen, Delft, The Netherlands; ${ }^{13}$ PAR Lite, Kipp \& Zonen, Delft, The Netherlands; ${ }^{14}$ LAS MkII Scintillometer, Kipp \& Zonen, Delft, The Netherlands; ${ }^{15}$ RPG-MWSC-160, RPG Radiometer Physics GmbH, Meckenheim, Germany; ${ }^{16}$ WXT520 Vaisala weather transmitter, Vaisala, Helsinki, Finlandia; ${ }^{17}$ XT-DTS, Silixa, Elstree, UK; ${ }^{18}$ Atmos-22, METER Group, Inc., Pullman, WA, USA; ${ }^{19}$ DS-2, Decagon Devices, Pullman, WA, USA; ${ }^{20}$ VP-3 Vapor pressure, humidity and temperature sensor, Decagon Devices, Pullman, WA, USA; ${ }^{21}$ VP-4 Vapor pressure, humidity, temperature and atmospheric pressure sensor, Decagon Devices, Pullman, WA, USA; ${ }^{22}$ LI-200R Pyranometer, LI-COR, Inc., Lincoln, NE, USA $;{ }^{23}$ CS215 Temperature and relative humidity, Campbell Sci., Logan, UT, USA; ${ }^{24}$ TE525MM Metric Rain Gage, Campbell Sci., Logan, UT, USA.


Figure 3. Cont. 



Figure 3. Photographs of the instrumentation used in the E-DATA field campaign: (a) Salar del Huasco lagoon during the morning; (b) meteorological station 1 of the EW transect (EW1); (c) meteorological station 1 of the NS transect (NS1); (d) EC-water; (e) EC-desert; (f) EC-wet-salt; (g) OMS Receptor; (h) DTS system in which the cool and ambient reservoirs are shown; (i) radiosonde preparation at the lagoon; (j) radiosonde launched at the desert location; and (k) UAV with the atmospheric sensor.

\subsubsection{Meteorological Stations}

Two meteorological station transects -each comprised by four stations- were deployed (Table 2). The NS and EW transects shown in Figure 2 were selected to coincide with the predominant dayand night-time wind directions and considering the closed basin conceptual model suggested by Whiteman et al. [29]. As described before, these directions were obtained from both the in-situ observations of the CEAZA meteorological station and the WRF simulation results. The spacing between the meteorological stations was defined to have only one station per cell in the fine domain (D04 in Figure 1c) of the WRF simulations. Figure 3b,c present photographs of some of these stations. The meteorological data from these transects were collected at 2-m height, 5-min intervals, and were complemented with the data from the CEAZA meteorological station, which collects data at 60-min intervals. 
Table 2. Geographical information of the meteorological stations, eddy covariance (EC) systems, and optical-microwave scintillometer (OMS). OMS-Tx and OMS-Rx refer to the OMS transmitter and receiver, respectively.

\begin{tabular}{ccccc}
\hline Name of Station & Type & Latitude & Longitude & Elevation (m.a.s.1.) \\
\hline Salar del Huasco & Met. station & $20^{\circ} 15.5^{\prime} \mathrm{S}$ & $68^{\circ} 52.4^{\prime} \mathrm{W}$ & 3803 \\
NS1 & Met. station & $20^{\circ} 19.3^{\prime} \mathrm{S}$ & $68^{\circ} 52.9^{\prime} \mathrm{W}$ & 3807 \\
NS2 & Met. station & $20^{\circ} 20.6^{\prime} \mathrm{S}$ & $68^{\circ} 53.7^{\prime} \mathrm{W}$ & 3921 \\
NS3 & Met. station & $20^{\circ} 21.8^{\prime} \mathrm{S}$ & $68^{\circ} 54.3^{\prime} \mathrm{W}$ & 3973 \\
NS4 & Met. station & $20^{\circ} 23.0^{\prime} \mathrm{S}$ & $68^{\circ} 55.0^{\prime} \mathrm{W}$ & 3996 \\
EW1 & Met. station & $20^{\circ} 17.3^{\prime} \mathrm{S}$ & $68^{\circ} 54.1^{\prime} \mathrm{W}$ & 3938 \\
EW2 & Met. station & $20^{\circ} 17.2^{\prime} \mathrm{S}$ & $68^{\circ} 54.9^{\prime} \mathrm{W}$ & 4134 \\
EW3 & Met. station & $20^{\circ} 17.4^{\prime} \mathrm{S}$ & $68^{\circ} 56.4^{\prime} \mathrm{W}$ & 4139 \\
EW4 & Met. station & $20^{\circ} 17.1^{\prime} \mathrm{S}$ & $68^{\circ} 58.5^{\prime} \mathrm{W}$ & 4284 \\
EC-water & EC/Met. Station & $20^{\circ} 16.2^{\prime} \mathrm{S}$ & $68^{\circ} 52.8^{\prime} \mathrm{W}$ & 3790 \\
EC-desert & EC/Met. Station & $20^{\circ} 21.0^{\prime} \mathrm{S}$ & $68^{\circ} 54.0^{\prime} \mathrm{W}$ & 3953 \\
EC-wet-salt & EC/Met. Station & $20^{\circ} 16.8^{\prime} \mathrm{S}$ & $68^{\circ} 52.2^{\prime} \mathrm{W}$ & 3790 \\
OMS-Tx & Scintillometer & $20^{\circ} 17.1^{\prime} \mathrm{S}$ & $68^{\circ} 52.6^{\prime} \mathrm{W}$ & 3791 \\
OMS-Rx & Scintillometer/ & $20^{\circ} 16.8^{\prime} \mathrm{S}$ & $68^{\circ} 53.3^{\prime} \mathrm{W}$ & 3790 \\
\hline
\end{tabular}

\subsubsection{Evaporation Measurement Systems and Surface Energy Balance}

To understand the evaporation dynamics and the surface energy balance over heterogeneous surfaces and at different spatial scales, we used three EC systems (IRGASON, Campbell Sci., Logan, UT, USA) and one OMS (see Figure 2 and Table 2).

The first EC system, named EC-water, was deployed in the north part of the saline lake (1.5-m height), as shown in Figure $3 \mathrm{~d}$, taking advantage of its shallow water level $(\sim 0.07-0.15 \mathrm{~m})$. The second EC system (EC-desert) was installed $\sim 5 \mathrm{~km}$ south from the salt flat (2.5-m height), in a location where there is sparse vegetation and mostly rocky soil (Figure 3e). The third EC system, called EC-wet-salt, was located to the east of the lagoon in a wet-salt crust (2.0-m height, Figure 3f). All these EC systems had their footprint within the surfaces described before for the afternoon's wind regime, which is responsible for the large actual evaporation rates. Note also that the EC systems allowed to measure $\mathrm{CO}_{2}$ fluxes in the lagoon and its surroundings. The EC data were analyzed using the EddyPro 6.2.2 software and activating the default recommended correction procedures [36]. The EC data were obtained at $20 \mathrm{~Hz}$ and averaged using 10-min intervals.

The OMS, shown in Figure 3g, is composed of a large aperture scintillometer (LAS MkII, Kipp \& Zonen) and a microwave scintillometer (MWS, RPG-MWSC-160, Radiometer Physics GmbH), and measures simultaneously sensible $(H)$ and latent $(L E)$ heat fluxes over heterogeneous terrains $[37,38]$. The OMS was deployed in a $\sim 1.1 \mathrm{~km}$ path, with an effective height of $2.8 \mathrm{~m}$ and in the east-west direction. The OMS was installed in the northern end of the saline lake (Figure 2), with its path perpendicular to the main wind direction, and its estimated footprint covered the water from the saline lake and the wet salt. A novel aspect of the E-DATA field campaign is that it is the first time that an OMS is used in an open water body. The OMS data were averaged using 10-min intervals, and analyzed using the structure parameter coefficients defined by Ward et al. [39], the temperature-humidity correlation coefficient estimated through the Hill et al. [40] method, and the Monin-Obukhov similarity theory (MOST) stability functions described by Kooijmans and Hartogensis [41].

To investigate the surface energy balance, each EC system had different radiometers to estimate net radiation $\left(R_{n}\right)$, as well as heat flux plates to measure the ground heat flux $(G)$ at a specific depth $(31 / 32$ Heat flux meter, TNO Institute of Applied Physics, The Netherlands; HFP01 and HFP01SC heat flux sensors, Hukseflux, Delft, The Netherlands). At the water surface, the four components of radiation were measured (CNR4 Net radiometer, Kipp \& Zonen, Delft, The Netherlands). At the desert surface, only the net shortwave and net longwave radiation were available (CNR2 Net radiometer, Kipp \& Zonen, Delft, The Netherlands), whereas at the wet-salt surface only an integrated measurement of net radiation was 
collected (NR2 Lite, Kipp \& Zonen, Delft, The Netherlands). Additionally, the thermal conductivity and the volumetric heat capacity of the water, wet salt and desert were measured using a thermal properties analyzer (KD2 Pro, Decagon Devices, Pullman, WA, USA). These properties were used to estimate G at the surface of each measuring location using the calorimetric method to account for heat storage [42].

No efforts were made to measure evaporation in the wetlands of the northern end of the saline lake (see Figure 2), located downwind, as our main interest was to investigate the impact of advection on the evaporation rates at the lake.

\subsubsection{ABL Investigation Using Radiosondes and an UAV}

To have detailed information of the ABL, a radiosonde campaign was performed between 18 and 22 November 2018 (Table 3). We combined a relatively small balloon for boundary layer radiosounding with the iMet-4 Radiosonde (InterMet Systems, Grand Rapids, MI, USA) to obtain temperature, humidity, wind speed and direction, and height. Radiosondes were launched from the saline lake (near the receptor of the OMS) and from the desert (where EC-desert was deployed) (Figure 2), for a total of 16 radiosondes launched during the E-DATA field experiment. Figure 3i,j show photographs of the radiosonde launching at the salt flat and at the desert location, respectively.

Table 3. Schedule of the radiosonde campaign.

\begin{tabular}{cccccc}
\hline Date and Local Time & Location & Date and Local Time & Location & Date and Local Time & Location \\
\hline 18 November 2018 09:00 & Lake & 21 November 2018 09:00 & Lake & 22 November 2018 09:00 & Desert \\
18 November 2018 12:00 & Lake & 21 November 2018 12:00 & Lake & 22 November 2018 12:00 & Desert \\
18 November 2018 18:00 & Lake & 21 November 2018 15:00 & Lake & 22 November 2018 15:00 & Desert \\
19 November 2018 09:00 & Desert & 21 November 2018 18:00 & Lake & 22 November 2018 17:00 & Desert \\
19 November 2018 12:00 & Desert & 21 November 2018 21:00 & Lake & 22 November 2018 21:00 & Desert \\
19 November 2018 18:00 & Desert & & & & \\
\hline
\end{tabular}

To complement the radiosonde campaign, detailed observation of pressure, temperature and relative humidity at elevations between 0 and $500 \mathrm{~m}$ above the saline lake and above the desert were performed with an atmospheric sensor (iMet-XQ2, InterMet, Grand Rapids, MI, USA) installed in an UAV (Phantom 4 Professional, DJI, Shenzhen, Guangdong, China), as shown in Figures 2 and 3k. In this case, the ABL information was obtained with a resolution of $\sim 1 \mathrm{~m}$. The UAV flights were performed every $30 \mathrm{~min}$ between 9:00 and 12:00 LT. On 21 November the flights were carried out above the saline lake, and on 22 November the flights were performed above the desert (Figure 2). Due to the strong winds during the afternoon, no flights were performed after 12:00 LT.

\subsubsection{DTS Measurements}

A DTS system (XT-DTS, Silixa, Elstree, UK) was deployed near the location of the OMS with the aim of capturing the horizontal temperature variation along bare ground, air above the ground and lagoon, and at the water-sediment interface (see DTS transect in the inset of Figures 2 and $3 \mathrm{~h}$ for a photograph of the DTS base station). Approximately $620 \mathrm{~m}$ of a $900 \mu \mathrm{m}$ tight-buffered fiber-optic cable (AFL Telecommunications, Duncan, SC, USA) were used in this deployment. Approximately $50 \mathrm{~m}$ were used for calibration purposes, $\sim 100 \mathrm{~m}$ were on the ground surface, $\sim 450 \mathrm{~m}$ were deployed at $\sim 30-40 \mathrm{~cm}$ above the water surface (with $\sim 325 \mathrm{~m}$ deployed in the east-west direction and $\sim 125 \mathrm{~m}$ installed in the southwest-northeast direction), and $\sim 20 \mathrm{~m}$ submerged at the water-sediments interface ( $\sim 10-15 \mathrm{~cm}$ depth). The fiber-optic cable was connected to the DTS instrument that collected temperature data with a spatial resolution of $\sim 0.5 \mathrm{~m}$ (sampling resolution of $0.25 \mathrm{~m}$ ) and an integration time of $15 \mathrm{~s}$. The DTS system was calibrated using the manufacturer calibration software and using a single-ended configuration [43,44].

\subsection{5. $\mathrm{CO}_{2}$ Flux and Meteorological Conditions}

To study the link between meteorological conditions and the biochemical dynamics of open waters in the saline lake was also an objective of the E-DATA field campaign. Particularly, to investigate 
the relationship between the wind magnitude and the $\mathrm{CO}_{2}$ flux exchanged between the atmosphere and the saline lake. To study this link is motivated by the fact that the ecological description of these ecosystems indicates that the trophic chain is supported by benthic primary production (BPP) that occurs in the sediments of the saline lake [45-47]. BPP occurs in a thin active layer at the top of the sediments $[25,48,49]$, and it is due to the photosynthesis of benthonic species such as benthic diatoms and cyanobacteria $[6,50]$.

To relate meteorological factors and the $\mathrm{CO}_{2}$ fluxes exchanged between the atmosphere and the saline lake, several biogeochemical parameters were measured. $\mathrm{CO}_{2}$ fluxes were collected in the three EC systems (IRGASON, Campbell Sci., Logan, UT, USA). In the saline lake, the water temperature and DO were continuously measured using the HOBO U26 Dissolved Oxygen Data Logger (Onset Computer Corporation, Bourne, MA, USA). Turbidity was measured with the Cyclops-7 turbidity sensor and loggers (PME, Inc., Vista, CA, USA). All of these measurements were collected at approximately $3 \mathrm{~cm}$ above the water-sediment interface. Because of the shallowness of the lake ( 10 cm depth [25]), the water column is well-mixed. Hence, these measurements are representative of the entire water column.

\section{Results}

To be concise, and given that the results are relatively similar among the different days of the field campaign, they are presented and discussed for specific days that are considered representative of the whole experiment. For this reason, and to avoid showing days with too many data gaps, we selected 15 and 17 November 2018 as examples of the collected data.

\subsection{Meteorological Data}

The data collected in both transects of meteorological stations show a similar behavior. For conciseness, we only present the data collected in the EW transect for 15 November 2018 (Figure 4). Two wind regimes are observed from the meteorological data. The first regime occurs during the morning where both wind speed and specific humidity are small. The second regime occurs between 12:00 and 21:00 LT, when air circulation coming from the west increases wind speed up to $\sim 12 \mathrm{~m} \mathrm{~s}^{-1}$ and brings air with a specific humidity of $\sim 3.5 \mathrm{~g} \mathrm{~kg}^{-1}$ into the basin. The afternoon wind regime also results in a sudden decrease of potential temperature, thus controlling the daily cycle of the meteorological conditions.
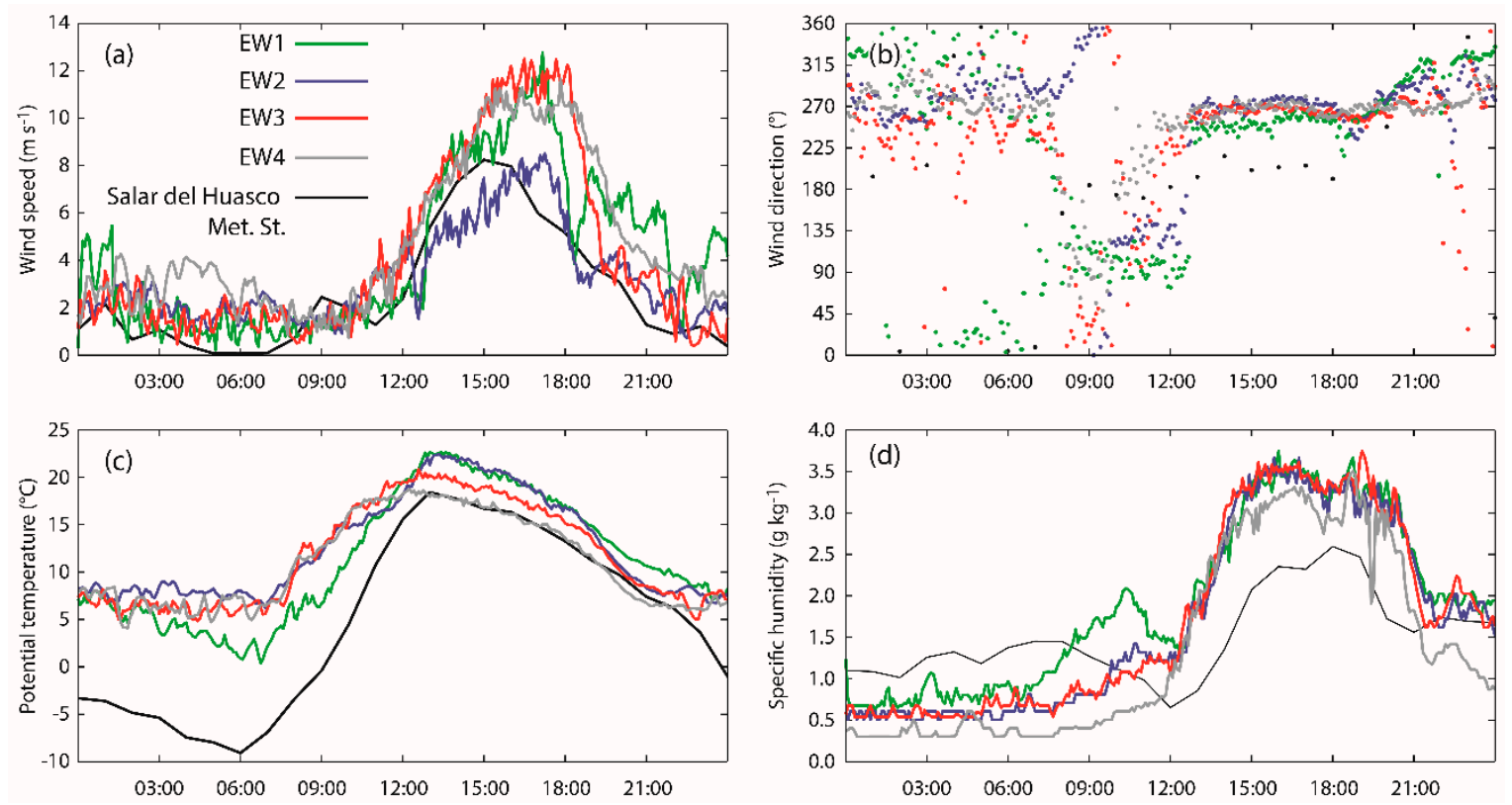

Figure 4. Meteorological data obtained in the EW transect for 15 November 2018: (a) wind speed; (b) wind direction; (c) potential temperature; and (d) specific humidity. The location of the meteorological stations is shown in Figure 2. 


\subsection{Evaporation and Surface Energy Balance}

The characterization of the surface energy fluxes at the water, desert and wet-salt surfaces measured with the EC systems is shown in Figure 5 for 17 November 2018. Also, the energy balance closure is presented for the entire field campaign. Over the water surface, $L E$ and $G$ were the dominant surface heat fluxes with maximum values reaching $\sim 400$ and $\sim 550 \mathrm{~W} \mathrm{~m}^{-2}$, respectively, whereas the maximum $H$ values were of $\sim 100 \mathrm{~W} \mathrm{~m}^{-2}$ (Figure 5a). The total daily evaporation in this day was of $4.3 \mathrm{~mm}$. The orthogonal regression for the energy balance at the water surface-calculated using 10-min integration time- had a slope of 0.58 with an $r^{2}=0.89$ (Figure 5b). At the desert surface, the $H$ was dominant with maximum values of $\sim 450 \mathrm{~W} \mathrm{~m}^{-2}$ and $\mathrm{G}$ reached maximum values of $\sim 200 \mathrm{~W} \mathrm{~m}^{-2}$, with almost zero $L E$ (Figure 5c). A total evaporation of $0.1 \mathrm{~mm}$ was measured for this day. As shown in Figure $5 d$, the slope of the energy balance orthogonal regression was of $0.77\left(r^{2}=0.92\right)$. $G$ was the dominant surface heat flux at the wet-salt surface with maximum values of $\sim 350 \mathrm{~W} \mathrm{~m}^{-2}$, and the maximum values of $H$ reached $\sim 250 \mathrm{~W} \mathrm{~m}^{-2}$. The maximum $L E$ values are small and of the order of $\sim 60 \mathrm{~W} \mathrm{~m}^{-2}$ (Figure 5e). The total daily evaporation in this day was of $0.5 \mathrm{~mm}$. The slope of the energy balance was of 0.79 , with $r^{2}=0.84$ (Figure $5 \mathrm{f}$ ).
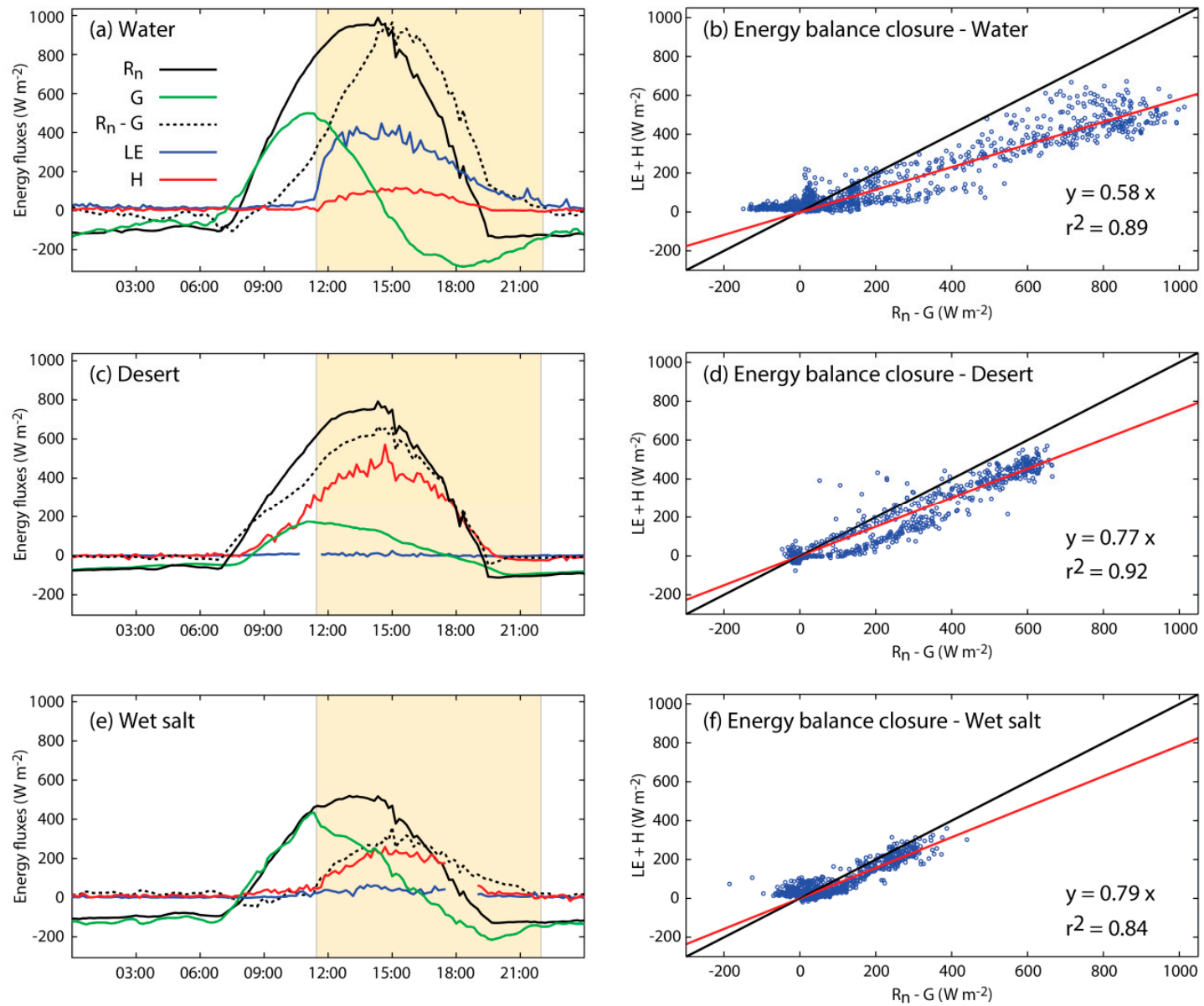

Figure 5. Characterization of the surface energy fluxes at the water, wet salt and desert surfaces, measured with the EC systems using an integration time of $10 \mathrm{~min}$ (17 November 2018). Left: temporal daily evolution of the surface energy fluxes $\left(R_{n}, G, L E\right.$ and $\left.H\right)$ and the available energy $\left(R_{n}-G\right)$ for the water (a), desert (c) and wet-salt (e) surfaces. The yellow background corresponds to the time period of the afternoon wind regime in which the wind speed is significant $\left(>\sim 4 \mathrm{~m} \mathrm{~s}^{-1}\right)$. Right: energy balance closure at the water (b), desert (d) and wet-salt (f) surfaces. The black line corresponds to the 1:1 line, the red line is the fitted line from orthogonal regression and the dots correspond to the 10-min values of $\left(R_{n}-G\right)$ and $(L E+H)$. 
A comparison of the surface energy fluxes at the water, measured by the EC-water system and the OMS on 15 November 2018, reveals that the EC system measures a larger $L E$ than that measured by the OMS (Figure 6). Accordingly, the $H$ measured by the EC system is lower than that of the OMS. The maximum values of $L E$ and $H$ measured with the OMS are of $\sim 300$ and $\sim 120 \mathrm{~W} \mathrm{~m}^{-2}$, respectively. The differences between the surface energy fluxes measured by the EC-water and OMS are expected as their footprints are different. The EC-water system had its footprint on the saline lake, whereas the OMS footprint falls mainly over the water, but also cover a small part of the wet salt (Figure 2). As shown in Figure 5, LE in the wet salt is almost zero, whereas the $H$ is larger than that measured by the EC-water system. Therefore, one would expect to have smaller values of $L E$ and larger values of $H$ in the OMS measurements compared to those of the EC-water system (Figure 6).

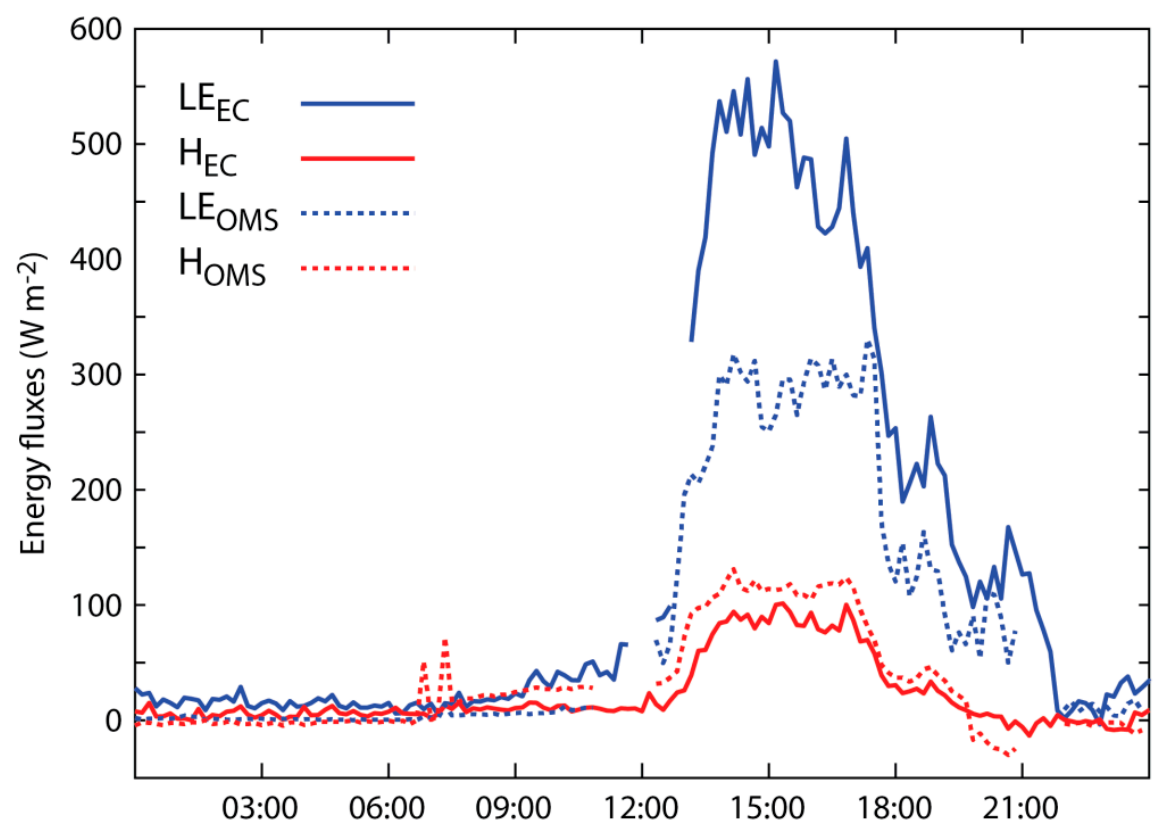

Figure 6. Latent $(L E)$ and sensible $(H)$ heat fluxes measured by the EC-water system and the OMS (15 November 2018).

\subsection{Diurnal Evolution of the Boundary Layer Structure}

The results of the radiosonde campaign and UAV flights obtained over the lake (21 November 2018) and the desert (22 November 2018) are presented in Figure 7. The vertical profile measurements show a complex thermal diurnal evolution of the ABL vertical structure (Figure 7a,b). As shown in Figure 7a, above the water, a thermal stratification exists during the morning (09:00-12:00 LT), whereas in the afternoon, a strong capping (15:00 LT) followed by an unstable boundary layer are observed. In the evening (20:00 LT), a relatively shallow well-mixed boundary layer $(\sim 400 \mathrm{~m})$ is observed. In terms of specific humidity, the boundary layer goes from a very dry and windless condition to a less dry windy condition. At the desert location, there is a convective evolution from thermally stratified structure to a well-mixed boundary layer that reaches a height of $\sim 1500 \mathrm{~m}$ at noon (Figure $7 \mathrm{~b}$ ). In the afternoon, an internal cooler and moister 600-m thick boundary layer is observed (15:00 to 18:00 LT), and a strong wind from the southwest persists in the first $1800 \mathrm{~m}$ above the ground until the evening (20:00 LT).

The results obtained from the UAV flights reveal the details of the thermal vertical structure of the first $\sim 450 \mathrm{~m}$ within the ABL that develops during the morning. The measurements above the water and the desert surfaces obtained from the UAV flights agree with those collected with radiosoundings, although the UAV data has better spatial and temporal resolution. Recall that UAV data were only collected in the morning due to strong winds during the afternoon. Above the water, there is a cool air that is well-mixed in the first $200 \mathrm{~m}$. Then, the air presents a strong stratification even until midday 
(Figure 7c). At the desert location, a normal convective boundary layer growth is observed, where at 09:30 a stratified layer is formed that rapidly mixes towards midday (Figure 7d).
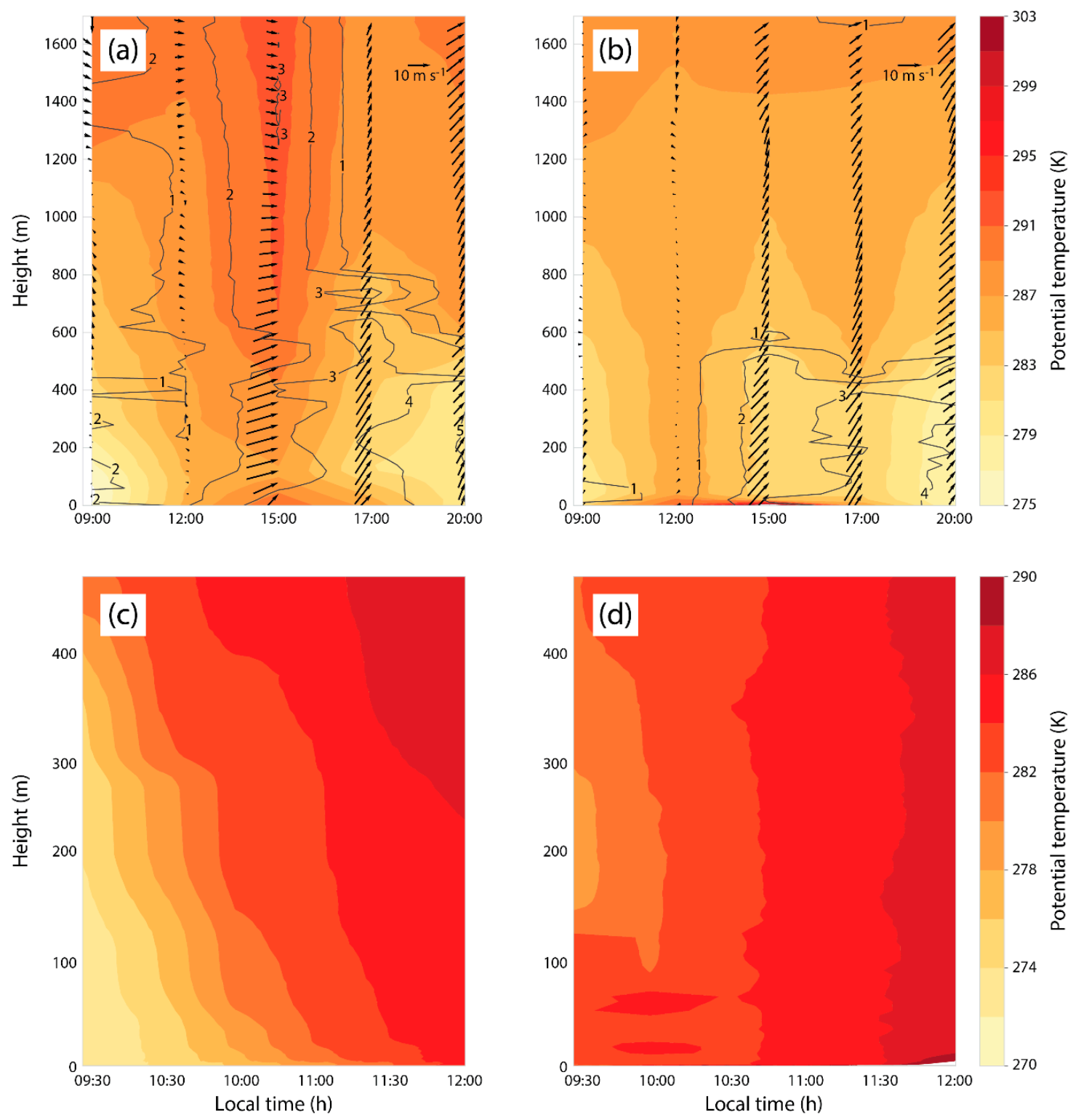

Figure 7. Diurnal evolution of the vertical profiles of potential temperature (K, colors), specific humidity ( $\mathrm{g} \mathrm{kg}^{-1}$, solid lines) and horizontal wind speed and wind direction $\left(\mathrm{m} \mathrm{s}^{-1}\right.$, arrows) measured with the radiosoundings. Measurements performed on 21 November 2018 above the saline lake (a) and on 22 November 2018 above the desert (b). Conventional directions and arrow lengths are shown at the top of panels (a) and (b). Morning evolution of the potential temperature measured with the UAV on 21 November 2018 above the saline lake (c) and on 22 November 2018 above the desert (d). Note the different height and temperature scales between the radiosondes and UAV data.

\subsection{DTS Data}

Representative thermal profiles obtained with the DTS system during midday (12:30 LT) and during nighttime (00:30 LT) are shown in Figure 8a. A large variability of surface temperatures is observed during the day in the bare ground with differences of up to $\sim 20^{\circ} \mathrm{C}$. Above the water surface, the air temperatures near the shore of the lagoon were warmer than those observed towards the lagoon center. During night, the opposite behavior occurs: cool and more stable ground temperatures were 
observed, and the air temperature above the lagoon center was warmer than that near the shore. During day- and night-time, the water-sediments interface temperature was relatively uniform, and variations of up to $\sim 15{ }^{\circ} \mathrm{C}$ were observed along the daily cycle.
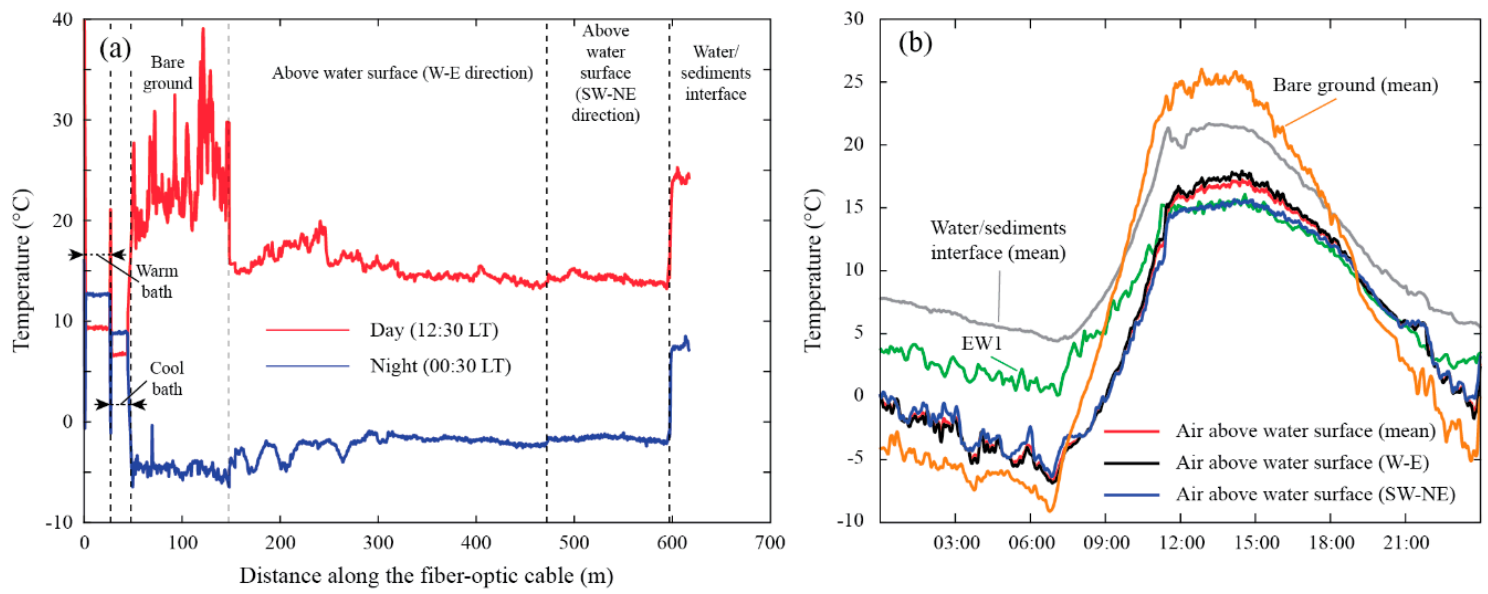

Figure 8. (a) DTS data that shows representative thermal profiles along the optical fiber for dayand night-time. The warm and cool bath are sections along the cable used for calibration purposes. (b) Temperatures measured with the EW1 meteorological station and the DTS system (17 November 2018). The DTS temperatures shown correspond to the mean values of the different sections depicted in Figure 8a, and are integrated over 5-min to have the same time interval than the records of the EW1 meteorological station.

The temperature time series obtained with the DTS system reveal that there are significant differences between the temperatures measured at the different sections of the fiber-optic cable (Figure $8 b$ ). The temperature of the bare ground exhibits a greater amplitude than that of the air and of the water-sediments interface. Further, the DTS air temperatures differ by more than $3^{\circ} \mathrm{C}$ with those measured by EW1 during the morning windless regime, and there are also differences of $\sim 2{ }^{\circ} \mathrm{C}$ during the afternoon wind regimen between the air temperature measured in sections along the cable that were deployed in different directions (W-E and SW-NE directions). These results highlight the richness of the collected data and highlight that multiple observations are needed both spatially and temporally to understand the different physical processes that occur at the study site.

\section{5. $\mathrm{CO}_{2}$ Fluxes and Biochemical Data Results}

A typical time series of the diverse on-line variables measured during the field experiment are presented in Figure 9. The summary of these observations shows the $\mathrm{CO}_{2}$ fluxes were directed downwards, implying the saline lake is acting as a $\mathrm{CO}_{2}$ sink. Furthermore, the magnitude of the $\mathrm{CO}_{2}$ flux (blue area in Figure 9B) is determined by the afternoon wind $\left(u_{*}\right.$, wind shear velocity, measure for mechanical turbulent mixing), and the incident solar radiation $\left(R_{s w}\right)$. On the one hand, wind cycles in the Altiplano region are characterized by calm conditions during the morning and windy conditions in the afternoon [11,25]. As shown in Figure 9b, this diurnal meteorological cycle has direct influence on other observed variables, thus increasing the magnitude of the $\mathrm{CO}_{2}$ flux, similar to evaporation (Figure 5) and the lake's turbidity due to sediment resuspension during the afternoon [25]. This dynamic behavior of the $\mathrm{CO}_{2}$ flux in the shallow lake is associated to exchanges with the atmosphere at the air-water interface, to benthic primary production during the day and respiration during the night, and other photochemical processes uniquely attributed to this extreme environment $[6,7,25,51]$.

With respect to the rest of the variables measured in the water column, water temperature (black line in Figure 9A) follows the characteristic diurnal cycle previously described by de la Fuente [25] and de la Fuente and Meruane [11]. Briefly, it is larger than the air temperature, reaching maximum values a couple of hours after the peak of the incident solar radiation, and minimum values right 
before the sunrise. The DO concentrations are maximum in the afternoon under windy conditions and start to decrease after sunset, reaching minimum values at sunrise. Specific details are also observed in the DO time series and needs further analysis. For example, a drastic reduction of the DO concentration was observed at noon of 16 and 19 November (Figure 9A). DO dynamics are driven by mass exchanges between the saline lake and the atmosphere when the wind blows, and DO production by photosynthesis and biochemical consumption [25]. Since these drastic DO reductions occurred in cloudy days, as seen in the incoming shortwave radiation (Figure 9B), it is argued that these drastic changes in DO concentration may be due to rapid changes in the production/consumption ratio driven by cloud passing above the salt flat. However, the sudden drops in DO could also be an artifact as a result of sensor vibrations due to the onset of the strong afternoon winds.

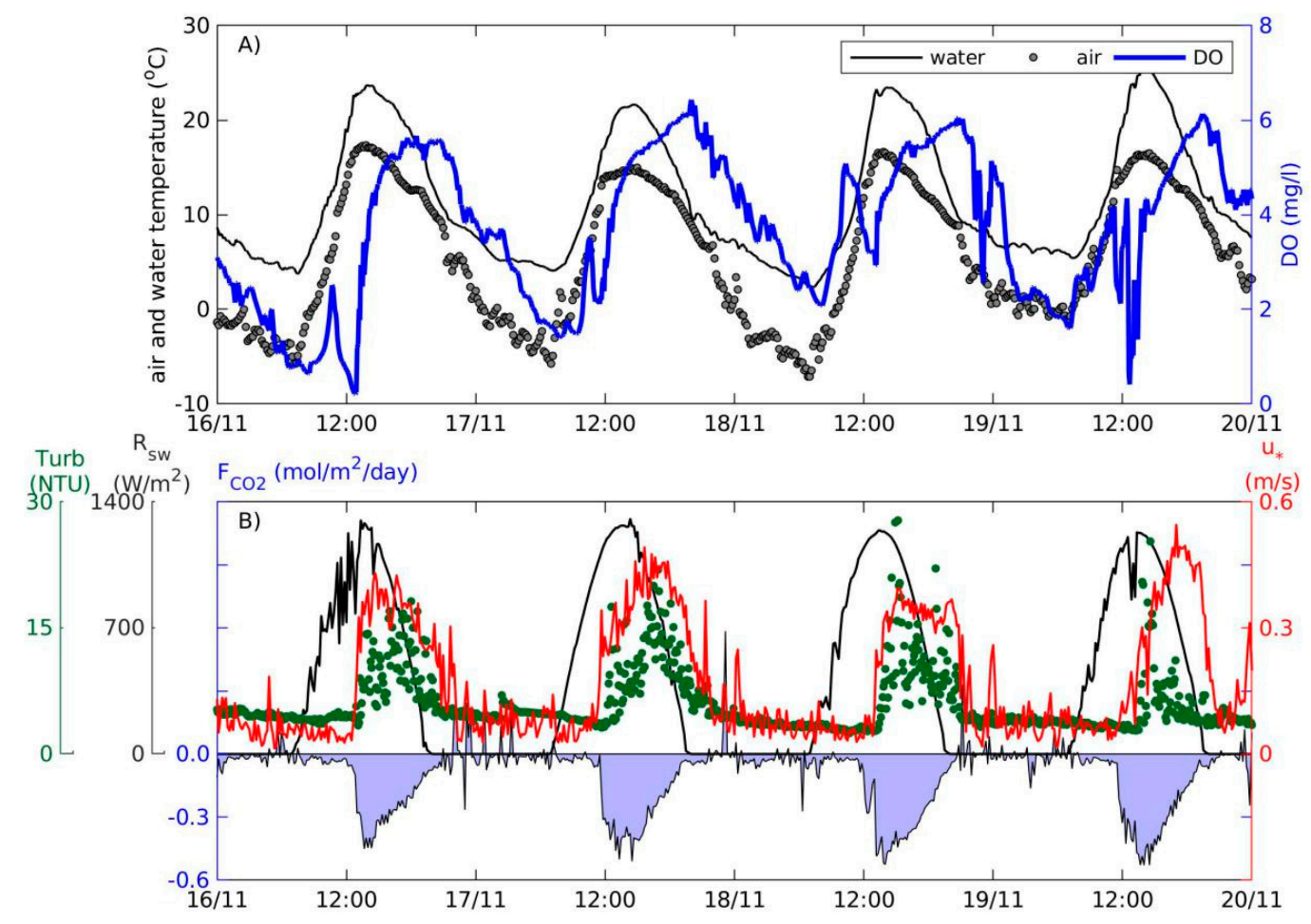

Figure 9. Field observation between 16 and 20 November 2018, in EC-water: (A) Time series of air and water temperature, and dissolved oxygen (DO); (B) time series of incident short wave radiation $\left(\mathrm{R}_{\mathrm{sw}}\right)$, wind shear velocity $(\mathrm{u} *)$, turbidity, and $\mathrm{CO}_{2}$ flux $\left(\mathrm{F}_{\mathrm{CO} 2}\right)$ exchanged between the air and the water (positive upward).

\section{Discussion}

The meteorological and EC data collected at the E-DATA field campaign clearly shows the control of surface and boundary-layer dynamics by two distinct regimes driven by synoptic and mesoscale conditions. The morning regime is characterized by low wind speeds $\left(<\sim 2 \mathrm{~m} \mathrm{~s}^{-1}\right)$ and low specific humidity values $\left(\sim 1.4 \pm 0.5 \mathrm{~g} \mathrm{~kg}^{-1}\right.$; mean \pm standard deviation of the entire field experiment); whereas the afternoon regime has high wind speeds $\left(\sim 12 \pm 2 \mathrm{~m} \mathrm{~s}^{-1}\right)$ and a specific humidity of $\sim 4.4 \pm 0.5 \mathrm{~g} \mathrm{~kg}^{-1}$, which still corresponds to dry air, but is much wetter than the air in the study site during the morning. Therefore, it is likely that the water source from the air that reaches the basin during the afternoon is not from the near surrounding desert.

At the water surface during the morning, the $R_{n}$ is mainly transformed into $G$, and $L E$ and $H$ remains very close to zero. However, at noon the wind speed significantly increases. As a result, $L E$ increases rapidly reaching actual values of $\sim 467 \pm 71 \mathrm{~W} \mathrm{~m}^{-2}\left(\sim 17.8 \pm 2.7 \mathrm{~mm} \mathrm{day}^{-1}\right)$. At that time, $H$ also increases reaching values of $\sim 111 \pm 13 \mathrm{~W} \mathrm{~m}^{-2}$. These energy fluxes agree with what has been 
reported by de la Fuente [25], in which $G$ reaches similar values to those measured in E-DATA. At the desert surface, a similar behavior than the water surface occurs although with the fact that almost no water is available for evaporation. Hence, when the wind speed increases most of the available energy is transformed into $H$, whereas $L E$ remains very close to zero. The energy partition at the wet-salt surface also strongly relies on the wind dynamics, with most of the $R_{n}$ being transformed into $G$ until the wind speed increases. At this point, most of the energy is released to the atmosphere as $H$. When analyzing what occurs at the open waters, it is interesting to note that although there is available energy and unlimited water for evaporation, this process is only triggered during the afternoon wind regime. During this regime, turbulent mixing due to wind is the main mechanism that allows heat and water vapor to exchange properties of the lake to the overlying atmosphere. Further research is needed to understand the mesoscale atmospheric circulation that generates the two wind regimes observed in the study site, which finally controls evaporation and other biogeochemical processes. Even when there are studies that have investigated the atmospheric circulation near the study site [10,52], as far as we know, no efforts have been made to understand these processes from a multiscale perspective. Further, as it is widely known that climate change can affect wind patterns [53-55], and that in the study site the reduction of the zonal wind has decreased the potential evaporation by $10 \%-20 \%$ compared to the second half of the twentieth century [11], it is important to ensure a continuous monitoring in order to quantify evaporation changes that will modify the water balance and biogeochemical processes of this high Andean wetland.

The rich data collected with the EC systems allow assessing the energy balance closure problem [56-58]. Our EC results have surface energy imbalances that range between $15 \%$ and $30 \%$ (Figure $5 b, d, f)$, which agree with several field experiments performed in the last decades [56]. This imbalance is higher in the desert and water surfaces. We hypothesize that our error in the energy balance is associated to: (1) the measurement of $R_{n}$ over the desert and wet-salt surfaces, as we used less accurate sensors that did not measure the four components of radiation, as opposed to the sensor used at the water surface; (2) the measurement of $G$, which was obtained at $5 \mathrm{~cm}$ depth. Consequently, $G$ was corrected to account for heat storage [42,59]. This correction process has a high level of uncertainty, especially in the water surface, which has a multilayer structure that also includes the sediments beneath the lake, and (3) the exchange processes on larger scales due to the heterogeneous landscape that have a significant influence on the energy balance [60].

As described before, the differences between the surface energy fluxes measured by the EC-water and OMS are expected as their footprints are different. Moreover, as this is the first time an OMS has been deployed in an open water body, there are other methodological aspects that must be assessed. Therefore, future analysis of these data should focus on evaluating the different methods to estimate the temperature-humidity correlation coefficient, e.g., using the Lüdi et al. [61] method, for investigating the applicability of the different MOST stability functions [41,62], and assessing different band pass filtering of the raw scintillometer signal [63]. Such analyses will allow for the refinement our first results.

The diurnal evolution of the ABL over the lake and the desert (Figure 7) depicts the complex feedback between the surface heat fluxes and the ABL itself [64]. This complexity follows also the two regimes that govern the surface fluxes. First, during the morning in absence of wind, a prototypical convective ABL is observed over the desert, whereas over the lake a well-mixed shallow ABL is observed at the beginning of the day. This well-mixed ABL evolves into a stratified layer in the late morning. As the $H$ is nearly zero during the morning (e.g., see Figure $5 a$ ), additional mechanisms must be occurring (described below). Second, during the afternoon a shallow internal boundary layer is formed over the lake and the desert. This internal boundary layer develops due to advection, which interrupts the normal growth of the convective ABL. This behavior has been reported in different environments $[65,66]$.

The DTS system not only allows observation of high spatial-resolution data, but also to discover other processes that must be further explored. For instance, the evaporation regime from the saline lake can be inferred combining the meteorological data and the water temperatures (e.g., see 
Adams et al. [67]). As the temperature of the saline lake was always warmer than that of air, as shown in Figures 8 and 9, we expect that during daytime the free-convective layer (or plume) evaporation regime occurs; whereas during the afternoon wind regime, it is likely to have the unstable or the neutral forced-convection layer evaporation regime [67]. During the morning, windless regime, however, our EC-data show that $H$ is nearly zero and that no evaporation occurs until 12:00 LT (e.g., see Figure 5a). These results suggest that between the air-water interface and the elevation of the EC system a stable air layer must be capping the water vapor that exits the lagoon. This air layer probably is very thin and is not mixed by the katabatic wind that occurs during the night and morning, which results in a mixed layer that has $\sim 60 \mathrm{~m}$ at sunrise, as our UAV flights revealed (e.g., see Figure $7 \mathrm{c}$ ). Moreover, other study showed that at the study site the lake water freezes [68], which complicates even more the understanding of the processes that are occurring at this thin boundary layer. As in other studies the DTS method has be successfully used to investigate the vertical temperature profile of the boundary layer that occurs at the air-water interface of similar systems with a spatial resolution of $\sim 0.005 \mathrm{~m}[44,69]$, we suggest that future research on this type of environments should use this technique to look with more details the vertical thermal structure of the air-water-sediments interface. These data will allow observing the temporal evolution of the thicknesses of the different boundary layers that occur in the system (within the air, water, or sediments) and to quantify the thermal gradients that occurs at the air-water-sediments interface, hence improving our understanding of the different fluxes that are involved at this interface.

Regarding the biochemical dynamics, we found that turbidity and $\mathrm{CO}_{2}$ flux measurements did show the effect of wind regimen on sediment resuspension, which has been related to light availability for photosynthesis at the sediments [25]. Based on these observations, our working hypothesis considers that the transport of $\mathrm{CO}_{2}$ across the air-water interface is also controlled by wind speed, thus highlighting the role of wind in BPP of the aquatic ecosystem. Furthermore, $\mathrm{CO}_{2}$ transport across the air-water interface is enhanced by wind speed that periodically occurs in the afternoon. In this sense, de la Fuente and Meruane [11] showed that changes in zonal wind patterns during the past decade have produced important changes in the potential evaporation. Conversely, these changes in wind patterns may also have produced important changes on BPP and the evaporation in the Salar del Huasco. Further research must continue towards understanding the main processes that explain the link between meteorological conditions and primary production of these system.

Even when we measured many relevant variables to investigate evaporation enhanced by advection, our field experiment had some limitations that are important to highlight, as they can be improved in future campaigns. First, due to instrument limitations, the surface energy balance fluxes $\left(R_{n}, G, L E\right.$ and $\left.H\right)$ were not measured in the dry salt crust of the salt flat and in the wetlands (also known as bofedales) located downwind the lake. To study evaporation enhanced by advection, knowing these fluxes is less relevant as knowing the fluxes at the water and desert surfaces, as the desert surface is in the lake's upwind direction. However, for water resources management, observation of the surface energy balance fluxes is relevant in the bofedales and in zones with shallow groundwater (in the lake's downwind direction, i.e., towards the north of the lake) [4]. In the case of the dry salt-crust surface, we expect low evaporation rates, in a similar way to what was observed by Kampf et al. [2] in the Salar de Atacama. Second, the month in which the observations were performed was defined to have the more optimal conditions to study advection episodes, i.e., near the end of the dry season. For water resources management, however, it would be desirable to have a continuous monitoring including the turbulent fluxes that allows observation of the relevant variables throughout the year, and to measure groundwater depths at different locations within the basin [4]. Third, our results suggest that during the morning a very thin stable boundary layer $(<\sim 1.5 \mathrm{~m})$ must be capping the water vapor that flows from the lagoon towards the atmosphere. Hence, to understand better the evaporation processes at the lake, a more detailed observation of the relevant meteorological variables is needed near the air-water interface. Fourth, our observations suggest that it is likely that the water source from the air that reaches the basin during the afternoon is not from the near surrounding desert. Therefore, it would 
be useful to combine WRF simulations with in-situ data collected outside the basin to track the air's water source. Finally, to improve our understanding of the link between meteorological conditions and biochemical dynamics of the Salar del Huasco, it would be interesting to measure $\mathrm{pH}$ and $\mathrm{CO}_{2}$ concentration for a full characterization of the vertical gradient that drives the $\mathrm{CO}_{2}$ flux exchanged between the atmosphere and water.

The E-DATA first results highlight the richness of the collected data sets and stress that, in order to understand the different physical and biogeochemical processes occurring in the Salar del Huasco, multiple observations are needed at different scales, both in space and time. Therefore, to quantify the water balance and the biogeochemical processes of this high Andean wetland, it is important to ensure continuous and detailed environmental monitoring.

\section{Conclusions}

In the endorheic basins of the Altiplano, water is crucial for sustaining unique ecological habitats, industry, and agriculture. Here, the wetlands act as highly localized evaporative environments, and little is known about the processes that control evaporation on space and on time. In this work, we presented the design and methods used in the 10-day E-DATA field campaign, and we discussed the implications of our first results for future research.

The E-DATA campaign was a specially designed experiment that combined ground and airborne measurements to understand the evaporation dynamics over heterogeneous surfaces, at different spatial scales in the Salar del Huasco, Chile, with main emphasis on open water evaporation, and accounting for the interaction between the ABL and the atmospheric regional circulation. The installation strategy of the instruments used in the field campaign was accomplished using the WRF model, which enabled to identify the best locations for meteorological stations, eddy covariance systems, scintillometers, and a DTS system. These measurements were complemented with an intensive radiosonde campaign and $\mathrm{UAV}$ flights for detailed profiling of the ABL. Additional water quality and $\mathrm{CO}_{2}$ fluxes measurements were performed to identify the relationship between meteorological conditions and the biochemical dynamics of the Salar del Huasco.

Our first findings show that evaporation in the Salar del Huasco is driven by processes occurring at multiple spatiotemporal scales. Two wind regimes are observed and identified from the meteorological data: the morning regime in which both wind speed and specific humidity are small (less than $2 \mathrm{~m} \mathrm{~s}^{-1}$ and $1.5 \mathrm{~g} \mathrm{~kg}^{-1}$, respectively), and the afternoon regime in which air circulation coming from the west yields an abrupt increase of both wind speed and specific humidity. Even in the case of available water and energy, i.e., over the saline lake, evaporation was triggered by mechanical turbulence induced by the wind. These two wind regimes also control the complex ABL dynamics observed at the study site. We show evidence of the strong correlation between the wind regimes and the evaporation and biochemical processes in Salar del Huasco. All the surface fluxes were enhanced and driven by the mechanical turbulence. Therefore, and with evidence that climate change can affect the wind patterns, it is necessary to ensure continuous monitoring and more detailed field campaigns in order to quantify the water balance and biogeochemical processes of high Andean wetlands.

Author Contributions: Conceptualization, F.S., F.L., A.d.1.F., J.V.-G.d.A. and O.H.; formal analysis, F.L., O.H., F.S.; all the authors contributed in the methodology and writing the manuscript; project administration, F.S.; funding acquisition, F.S. and A.d.l.F. All authors have read and agreed to the published version of the manuscript.

Funding: This research and the APC were funded by the Comisión Nacional de Investigación Científica y Tecnológica (CONICYT), by grants CONICYT/FONDECYT/1170850 and CONICYT/FONDECYT/1181222.

Acknowledgments: The authors thank the Centro de Desarrollo Urbano Sustentable (CEDEUS-CONICYT/FONDAP/15110020) and the Centro de Excelencia en Geotermia de los Andes (CEGA-CONICYT/FONDAP/15090013) for supporting this investigation. F. Lobos acknowledges support from the Wageningen University Ph.D. Sandwich Project N ${ }^{\circ}$ 5160957644. We acknowledge Matías Signorio, Catalina Aranguiz, Jaime Vergara, Fernanda Stegmaier, Matías Guerrero, María Cecilia Muñoz, Magdalena Mendoza, Raúl Urtubia and Tomás Oportus for supporting the E-DATA field experiment, and Rodrigo Escobar and Francisco Meza who made available some instruments. 
Conflicts of Interest: The authors declare no conflict of interest and declare that the funders had no role in the design of the study; in the collection, analyses, or interpretation of data; in the writing of the manuscript, or in the decision to publish the results.

\section{References}

1. Hernández-López, M.F.; Braud, I.; Gironás, J.; Suárez, F.; Muñoz, J.F. Modelling evaporation processes in soils from the Huasco salt flat basin, Chile. Hydrol. Process. 2016, 30, 4704-4719. [CrossRef]

2. Kampf, S.K.; Tyler, S.W.; Ortiz, C.A.; Muñoz, J.F.; Adkins, P.L. Evaporation and land surface energy budget at the Salar de Atacama, Northern Chile. J. Hydrol. 2005, 310, 236-252. [CrossRef]

3. de la Fuente, A.; Niño, Y. Temporal and spatial features of the thermohydrodynamics of shallow salty lagoons in northern Chile. Limnol. Oceanogr. 2010, 55, 279-288. [CrossRef]

4. Johnson, E.; Yáñez, J.; Ortiz, C.; Muñoz, J. Evaporation from shallow groundwater in closed basins in the Chilean Altiplano. Hydrol. Sci. J. 2010, 55, 624-635. [CrossRef]

5. Bredehoeft, J. It Is the Discharge. Groundwater 2007, 45, 523. [CrossRef]

6. Dorador, C.; Vila, I.; Remonsellez, F.; Imhoff, J.F.; Witzel, K.-P. Unique clusters of Archaea in Salar de Huasco, an athalassohaline evaporitic basin of the Chilean Altiplano. FEMS Microbiol. Ecol. 2010, 73, $291-302$. [CrossRef]

7. Dorador, C.; Vila, I.; Witzel, K.-P.; Imhoff, J.F. Bacterial and archaeal diversity in high altitude wetlands of the Chilean Altiplano. Fundam. Appl. Limnol. 2013, 182, 135-159. [CrossRef]

8. Evans, J.G.; McNeil, D.D.; Finch, J.W.; Murray, T.; Harding, R.J.; Ward, H.C.; Verhoef, A. Determination of turbulent heat fluxes using a large aperture scintillometer over undulating mixed agricultural terrain. Agric. For. Meteorol. 2012, 166-167, 221-233. [CrossRef]

9. Gunson, A.J.; Klein, B.; Veiga, M.; Dunbar, S. Reducing mine water requirements. J. Clean. Prod. 2012, 21, 71-82. [CrossRef]

10. Garreaud, R.; Vuille, M.; Clement, A.C. The climate of the Altiplano: Observed current conditions and mechanisms of past changes. Palaeogeogr. Palaeoclimatol. Palaeoecol. 2003, 194, 5-22. [CrossRef]

11. de la Fuente, A.; Meruane, C. Dimensionless numbers for classifying the thermodynamics regimes that determine water temperature in shallow lakes and wetlands. Environ. Fluid Mech. 2017, 17, 1081-1098. [CrossRef]

12. Philip, J.R. Advection, evaporation, and surface resistance. Irrig. Sci. 1987, 8, 101-114. [CrossRef]

13. De Bruin, H.A.R.; Hartogensis, O.K.; Allen, R.G.; Kramer, J.W.J.L. Regional Advection Perturbations in an Irrigated Desert (RAPID) experiment. Theor. Appl. Climatol. 2005, 80, 143-152. [CrossRef]

14. Kool, D.; Ben-Gal, A.; Agam, N. Within-field advection enhances evaporation and transpiration in a vineyard in an arid environment. Agric. For. Meteorol. 2018, 255, 104-113. [CrossRef]

15. Blanken, P.D.; Rouse, W.R.; Culf, A.D.; Spence, C.; Boudreau, L.D.; Jasper, J.N.; Kochtubajda, B.; Schertzer, W.M.; Marsh, P.; Verseghy, D. Eddy covariance measurements of evaporation from Great Slave Lake, Northwest Territories, Canada. Water Resour. Res. 2000, 36, 1069-1077. [CrossRef]

16. Liu, H.; Zhang, Y.; Liu, S.; Jiang, H.; Sheng, L.; Williams, Q.L. Eddy covariance measurements of surface energy budget and evaporation in a cool season over southern open water in Mississippi. J. Geophys. Res. Atmos. 2009, 114. [CrossRef]

17. Higgins, C.W.; Pardyjak, E.; Froidevaux, M.; Simeonov, V.; Parlange, M.B. Measured and Estimated Water Vapor Advection in the Atmospheric Surface Layer. J. Hydrometeorol. 2013, 14, 1966-1972. [CrossRef]

18. Shuttleworth, W.J. Putting the "vap" into evaporation. Hydrol. Earth Syst. Sci. 2007, 11, 210-244. [CrossRef]

19. Haghighi, E.; Gianotti, D.J.S.; Akbar, R.; Salvucci, G.D.; Entekhabi, D. Soil and Atmospheric Controls on the Land Surface Energy Balance: A Generalized Framework for Distinguishing Moisture-Limited and Energy-Limited Evaporation Regimes. Water Resour. Res. 2018, 54, 1831-1851. [CrossRef]

20. DIHA-PUC. Levantamiento hidrogeológico para el desarrollo de nuevas fuentes de agua en áreas prioritarias de la zona norte de Chile, regiones XV, I, II y III [Hydrogeological characterization for the development of new water supply sources in priority areas in northern Chile, regions XV, I., II and III]. In Final Report VIII, Pilot System, 1st Region: Salar Del Huasco; Department Ingeniería Hidráulica y Ambiental, Pontificia Universidad Católica de Chile and Dirección General de Aguas: Santiago, Chile, 2009. 
21. Stull, R. An Introduction to Boundary Layer Meteorology. Available online: https://www.springer.com/gp/ book/9789027727688 (accessed on 1 December 2019).

22. Vilà-Guerau de Arellano, J.; Heerwaarden, C.C.; van Stratum, B.J.H.; van den Dries, K. Atmospheric Boundary Layer: Integrating Air Chemistry and Land Interactions; Cambridge University Press: New York, NY, USA, 2015.

23. Skamarock, C.; Klemp, B.; Dudhia, J.; Gill, O.; Barker, D.; Duda, G.; Huang, X.; Wang, W.; Powers, G. A Description of the Advanced Research WRF Version 3; National Center for Atmospheric Research: Boulder, CO, USA, 2008.

24. Uribe, J.; Muñoz, J.F.; Gironás, J.; Oyarzún, R.; Aguirre, E.; Aravena, R. Assessing groundwater recharge in an Andean closed basin using isotopic characterization and a rainfall-runoff model: Salar del Huasco basin, Chile. Hydrogeol. J. 2015, 23, 1535-1551. [CrossRef]

25. de la Fuente, A. Heat and dissolved oxygen exchanges between the sediment and water column in a shallow salty lagoon. J. Geophys. Res. Biogeosci. 2014, 119, 596-613. [CrossRef]

26. Gardner, R.C.; Davidson, N.C. The Ramsar Convention. In Wetlands: Integrating Multidisciplinary Concepts; LePage, B.A., Ed.; Springer: Dordrecht, The Netherlands, 2011; pp. 189-203. ISBN 978-94-007-0551-7.

27. Houston, J. Variability of Precipitation in the Atacama Desert: Its Causes and Hydrological Impact -Houston -2006 -International Journal of Climatology -Wiley Online Library. Available online: https: //rmets.onlinelibrary.wiley.com/doi/abs/10.1002/joc.1359 (accessed on 14 November 2019).

28. Garreaud, R.; Aceituno, P. Interannual Rainfall Variability over the South American Altiplano. J. Clim. 2001, 14, 2779-2789. [CrossRef]

29. Whiteman, C.D.; Pospichal, B.; Eisenbach, S.; Weihs, P.; Clements, C.B.; Steinacker, R.; Mursch-Radlgruber, E.; Dorninger, M. Inversion Breakup in Small Rocky Mountain and Alpine Basins. J. Appl. Meteorol. 2004, 43, 1069-1082. [CrossRef]

30. Bretherton, C.S.; Park, S. A New Moist Turbulence Parameterization in the Community Atmosphere Model. J. Clim. 2009, 22, 3422-3448. [CrossRef]

31. Iacono, M.J.; Delamere, J.S.; Mlawer, E.J.; Shephard, M.W.; Clough, S.A.; Collins, W.D. Radiative forcing by long-lived greenhouse gases: Calculations with the AER radiative transfer models. J. Geophys. Res. Atmos. 2008, 113. [CrossRef]

32. Ek, M.B.; Mitchell, K.E.; Lin, Y.; Rogers, E.; Grunmann, P.; Koren, V.; Gayno, G.; Tarpley, J.D. Implementation of Noah land surface model advances in the National Centers for Environmental Prediction operational mesoscale Eta model. J. Geophys. Res. Atmos. 2003, 108. [CrossRef]

33. Lobos Roco, F.; Vilà-Guerau de Arellano, J.; Pedruzo-Bagazgoitia, X. Characterizing the influence of the marine stratocumulus cloud on the land fog at the Atacama Desert. Atmos. Res. 2018, 214, 109-120. [CrossRef]

34. Jiménez, P.A.; de Arellano, J.V.-G.; Dudhia, J.; Bosveld, F.C. Role of synoptic- and meso-scales on the evolution of the boundary-layer wind profile over a coastal region: The near-coast diurnal acceleration. Meteorol. Atmos. Phys. 2016, 128, 39-56. [CrossRef]

35. Dee, P.; Uppala, S.M.; Simmons, A.J.; Berrisford, P.; Poli, P.; Kobayashi, S.; Andrae, U.; Balmaseda, M.A.; Balsamo, G.; Bauer, P.; et al. The ERA-Interim reanalysis: Configuration and performance of the data assimilation system. Q. J. R. Meteorol. Soc. 2011, 137, 553-597. [CrossRef]

36. Fratini, G.; Mauder, M. Towards a consistent eddy-covariance processing: An intercomparison of EddyPro and TK3. Atmos. Meas. Tech. 2014, 7, 2273-2281. [CrossRef]

37. Beyrich, F.; De Bruin, H.A.R.; Meijninger, W.M.L.; Schipper, J.W.; Lohse, H. Results from One-Year Continuous Operation of a Large Aperture Scintillometer over a Heterogeneous Land Surface. Bound. Layer Meteorol. 2002, 105, 85-97. [CrossRef]

38. Meijninger, W.M.L.; Green, A.E.; Hartogensis, O.K.; Kohsiek, W.; Hoedjes, J.C.B.; Zuurbier, R.M.; De Bruin, H.A.R. Determination of Area-Averaged Water Vapour Fluxes with Large Aperture and Radio Wave Scintillometers over a Heterogeneous Surface-Flevoland Field Experiment. Bound. Layer Meteorol. 2002, 105, 63-83. [CrossRef]

39. Ward, H.C.; Evans, J.G.; Hartogensis, O.K.; Moene, A.F.; Bruin, H.A.R.D.; Grimmond, C.S.B. A critical revision of the estimation of the latent heat flux from two-wavelength scintillometry. Q. J. R. Meteorol. Soc. 2013, 139, 1912-1922. [CrossRef]

40. Hill, R.J. Algorithms for Obtaining Atmospheric Surface-Layer Fluxes from Scintillation Measurements. J. Atmos. Ocean. Technol. 1997, 14, 456-467. [CrossRef] 
41. Kooijmans, L.M.J.; Hartogensis, O.K. Surface-Layer Similarity Functions for Dissipation Rate and Structure Parameters of Temperature and Humidity Based on Eleven Field Experiments. Bound. Layer Meteorol. 2016, 160, 501-527. [CrossRef]

42. Heusinkveld, B.G.; Jacobs, A.F.G.; Holtslag, A.A.M.; Berkowicz, S.M. Surface energy balance closure in an arid region: Role of soil heat flux. Agric. For. Meteorol. 2004, 122, 21-37. [CrossRef]

43. Hausner, M.B.; Suárez, F.; Glander, K.E.; van de Giesen, N.; Selker, J.S.; Tyler, S.W. Calibrating Single-Ended Fiber-Optic Raman Spectra Distributed Temperature Sensing Data. Sensors 2011, 11, 10859-10879. [CrossRef]

44. Suárez, F.; Aravena, J.E.; Hausner, M.B.; Childress, A.E.; Tyler, S.W. Assessment of a vertical high-resolution distributed-temperature-sensing system in a shallow thermohaline environment. Hydrol. Earth Syst. Sci. 2011, 15, 1081-1093. [CrossRef]

45. Zúñiga, L.R.; Campos, V.; Pinochet, H.; Prado, B. A limnological reconnaissance of Lake Tebenquiche, Salar de Atacama, Chile. Hydrobiologia 1991, 210, 19-24. [CrossRef]

46. Dejoux, C. Benthic invertebrates of some saline lakes of the Sud Lipez region, Bolivia. Hydrobiologia 1993, 267, 257-267. [CrossRef]

47. Williams, W.D.; Carrick, T.R.; Bayly, I.A.E.; Green, J.; Herbst, D.B. Invertebrates in salt lakes of the Bolivian Altiplano. Int. J. Salt Lake Res. 1995, 4, 65-77. [CrossRef]

48. Revsbech, N.P.; Madsen, B.L.; Jørgensen, B. Oxygen production and consumption in sediments determined at high spatial resolution by computer simulation of oxygen microelectrode data. Limnol. Oceanogr. 1986, 31, 293-304. [CrossRef]

49. Ordoñez, C.; de la Fuente, A.; Díaz-Palma, P. Modeling the influence of benthic primary production on oxygen transport through the water-sediment interface. Ecol. Model. 2015, 311, 1-10. [CrossRef]

50. Demergasso, C.; Chong, G.; Galleguillos, P.; Escudero, L.; Martínez-Alonso, M.; Esteve, I. Tapetes microbianos del Salar de Llamará, norte de Chile. Rev. Chil. Hist. Nat. 2003, 76, 485-499. [CrossRef]

51. Dorador, C.; Vila, I.; Imhoff, J.F.; Witzel, K.-P. Cyanobacterial diversity in Salar de Huasco, a high altitude saline wetland in northern Chile: An example of geographical dispersion? FEMS Microbiol. Ecol. 2008, 64, 419-432. [CrossRef]

52. Rutllant, J.A.; Fuenzalida, H.; Aceituno, P. Climate dynamics along the arid northern coast of Chile: The 1997-1998 Dinámica del Clima de la Región de Antofagasta (DICLIMA) experiment. J. Geophys. Res. Atmos. 2003, 108, 4538. [CrossRef]

53. Ohba, M.; Sugimoto, S. Differences in climate change impacts between weather patterns: Possible effects on spatial heterogeneous changes in future extreme rainfall. Clim. Dyn. 2019, 52, 4177-4191. [CrossRef]

54. Stenseth, N.C.; Mysterud, A.; Ottersen, G.; Hurrell, J.W.; Chan, K.-S.; Lima, M. Ecological Effects of Climate Fluctuations. Science 2002, 297, 1292-1296. [CrossRef]

55. Vozila, A.B.; Güttler, I.; Ahrens, B.; Obermann-Hellhund, A.; Prtenjak, M.T. Wind Over the Adriatic Region in CORDEX Climate Change Scenarios. J. Geophys. Res. Atmos. 2019, 124, 110-130. [CrossRef]

56. Eder, F.; De Roo, F.; Kohnert, K.; Desjardins, R.L.; Schmid, H.P.; Mauder, M. Evaluation of Two Energy Balance Closure Parametrizations. Bound. Layer Meteorol. 2014, 151, 195-219. [CrossRef]

57. Charuchittipan, D.; Babel, W.; Mauder, M.; Leps, J.-P.; Foken, T. Extension of the Averaging Time in Eddy-Covariance Measurements and Its Effect on the Energy Balance Closure. Bound. Layer Meteorol. 2014, 152, 303-327. [CrossRef]

58. Russell, E.S.; Liu, H.; Gao, Z.; Finn, D.; Lamb, B. Impacts of soil heat flux calculation methods on the surface energy balance closure. Agric. For. Meteorol. 2015, 214-215, 189-200. [CrossRef]

59. Liebethal, C.; Foken, T. Evaluation of six parameterization approaches for the ground heat flux. Theor. Appl. Climatol. 2007, 88, 43-56. [CrossRef]

60. Foken, T. The energy Balance Closure Problem: An Overview. Ecol. Appl. 2008, 18, 1351-1367. [CrossRef]

61. Lüdi, A.; Beyrich, F.; Mätzler, C. Determination of the Turbulent Temperature-Humidity Correlation from Scintillometric Measurements. Bound. Layer Meteorol. 2005, 117, 525-550. [CrossRef]

62. Li, D.; Bou-Zeid, E.; De Bruin, H.A.R. Monin-Obukhov Similarity Functions for the Structure Parameters of Temperature and Humidity. Bound. Layer Meteorol. 2012, 145, 45-67. [CrossRef]

63. Stoffer, R. Revisiting Raw Data Processing of Combined Optical-Microwave Scintillometers. M.Sc. Thesis, Wageningen University \& Research, Wageningen, The Netherlands, 2018. 
64. van Heerwaarden, C.C.; Arellano, J.V.-G.; de Moene, A.F.; Holtslag, A.A.M. Interactions between dry-air entrainment, surface evaporation and convective boundary-layer development. Q. J. R. Meteorol. Soc. 2009, 135, 1277-1291. [CrossRef]

65. Raynor, G.S.; Sethuraman, S.; Brown, R.M. Formation and characteristics of coastal internal boundary layers during onshore flows. Bound. Layer Meteorol. 1979, 16, 487-514. [CrossRef]

66. Batchvarova, E.; Gryning, S.-E. Wind climatology, atmospheric turbulence and internal boundary-layer development in Athens during the MEDCAPHOT-TRACE experiment. Atmos. Environ. 1998, 32, 2055-2069. [CrossRef]

67. Adams, E.E.; Cosler, D.J.; Helfrich, K.R. Evaporation from heated water bodies: Predicting combined forced plus free convection. Water Resour. Res. 1990, 26, 425-435. [CrossRef]

68. Vergara, J. Estudio de la Variabilidad Intradiaria de los Flujos de Calor, Masa y Momentum en la Interfaz Aire-Agua de una Laguna Somera Salina del Altiplano Chileno; Universidad de Chile: Santiago, Chile, 2017.

69. Amigo, J.; Meza, F.; Suárez, F. A transient model for temperature prediction in a salt-gradient solar pond and the ground beneath it. Energy 2017, 132, 257-268. [CrossRef]

(C) 2020 by the authors. Licensee MDPI, Basel, Switzerland. This article is an open access article distributed under the terms and conditions of the Creative Commons Attribution (CC BY) license (http://creativecommons.org/licenses/by/4.0/). 